\title{
Integration of Indigenous Knowledge and Disaster Risk Reduction: A Case Study from Baie Martelli, Pentecost Island, Vanuatu
}

\author{
Rory A. Walshe ${ }^{1}$ and Patrick D. Nunn ${ }^{2, *}$ \\ ${ }^{1}$ Department of Geography, Environment and Disaster Management, Coventry University, Coventry CV1 5FB, United Kingdom \\ ${ }^{2}$ School of Behavioural, Cognitive and Social Sciences, University of New England, Armidale, New South Wales 2351, Australia
}

\begin{abstract}
Despite reaching heights of $>6 \mathrm{~m}$ and destroying a sizeable coastal settlement at the head of Baie Martelli (Pentecost Island, Vanuatu, South Pacific), the 26 November 1999 tsunamis caused only five fatalities from a threatened population of about 300 persons, most of whom fled inland and upslope before the waves struck. This remarkable survival rate is attributed to both indigenous knowledge, largely in the form of kastom knowledge, and information obtained from a video about tsunamis that was shown in the area three weeks earlier. Interviews with 55 persons who experienced this tsunami suggest that indigenous knowledge about tsunami risk and response in Baie Martelli was well known among key members of the community and was probably largely responsible for the appropriate response. Future strategies for disaster risk reduction should involve maintaining such indigenous knowledge in such communities and supplementing this where needed with scientific knowledge filtered through indigenous culture and language.
\end{abstract}

Keywords disaster risk reduction, indigenous knowledge, Pacific Islands, tsunami, Vanuatu

\section{Introduction}

Indigenous knowledge (IK) is the knowledge that was created by preliterate communities in response to various issues, most commonly those that stress or threaten a particular community or its livelihood. It is being increasingly acknowledged that indigenous knowledge can make important contributions to both the understanding and the management of environmental change in developing countries (Agrawal 1995; Mercer et al. 2007; Shaw, Sharma, and Takeuchi 2009). It has become clear that there are extant indigenous traditions that have elicited appropriate responses from communities confronted by disaster in ways that may be more effective than nonindigenous, science-based warning systems (McAdoo

\footnotetext{
* Corresponding author. E-mail: pnunn3@une.edu.au
}

et al. 2006; McAdoo, Moore, and Baumwoll 2009). Conversely, it is also apparent that many peripheral (distant from urban) communities in developing countries today lack such traditions and consequently have a need to interpret precursors of disaster to enable appropriate responses (Gregg et al. 2006; Gaillard et al. 2008).

Effective disaster risk reduction for communities in developing countries has been recognized by both national governments and development agencies over the past decade as key to sustainable development of these communities and nations, especially as indigenous knowledge systems are being eroded and other stressors like population pressure and climate change become felt more keenly (Schipper and Pelling 2006; Olorunfemi and Adebimpe 2008; Takeuchi, Mulyasari, and Shaw 2011). While it is clear that there are many ways in which messages about disaster risk reduction and climate change adaptation overlap and can therefore be communicated simultaneously, there remain distinct aspects of both that should not be overlooked by development planners (Kelman and Gaillard 2010; Mercer 2010).

These issues are well illustrated by Vanuatu (formerly the New Hebrides) in the South Pacific Ocean, an archipelagic nation that is uncommonly vulnerable to natural disasters, principally those associated with volcanism, earthquakes, and tropical cyclones (Pelling and Uitto 2001; Nunn 2009b; UNISDR 2009). Future climate change, while continuing to pose numerous challenges for Vanuatu, is unlikely to significantly alter the incidence of disasters linked to climate extremes, so this is one developing country where disaster risk reduction overlaps with climate change adaptation less than with others, particularly in the Pacific Islands region.

This article examines the responses of people in a peripheral part of Vanuatu to a 1999 earthquake and tsunami event, focusing on the sources of the knowledge that (1) informed these responses and (2) underpin people's current preparedness for a similar event in the future. The aim of the study is to understand the importance of indigenous knowledge in framing disaster responses as well as the value of supplementing this with nonindigenous information sources. 


\section{The Republic of Vanuatu, South Pacific Ocean}

Vanuatu is an elongated island group in which some 70 islands are permanently inhabited. The current population is around 258,000 who speak over 100 languages. Most people are engaged in subsistence farming and fishing although this is changing, as shown by the fact that 24 percent of the population is currently resident in urban areas which are growing at 4 percent annually. People have lived in Vanuatu for more than 3000 years and have a series of rich cultures to which indigenous knowledge, commonly expressed through oral traditions, is central. Since natural disasters are comparatively common in Vanuatu, indigenous (Ni-Vanuatu) cultures define them as normal and expected rather than exceptional (Galipaud 2002) although such traditional interpretations are being supplanted by global definitions.

Being located in the western part of the South Pacific Ocean, close to its warmest parts where most tropical cyclones develop, Vanuatu is affected more than any other island group in the region by tropical cyclones; it is considered the 7th most vulnerable country in the world to tropicalcyclone linked mortality (UNISDR 2009). Impacts of tropical cyclones vary. For example, while there were only two fatalities from Tropical Cyclone Ivy in 2004, it affected 25 percent of the population and caused USD 6 million of damage. In the affected communities 90 percent of the water supply systems were compromised, along with 70 percent of roads, 60 percent of health infrastructure, 80 percent of food crops, and 112 schools (McKenzie, Prasad, and Kaloumaira 2005).

Vanuatu is also at risk from earthquakes because most of its islands formed along a convergent lithospheric plate boundary (Vanuatu Trench) that continues to be active. More than 60 percent of its people and more than 90 percent of its GDP are exposed to earthquakes, making it the world's most earthquake-exposed country (UNISDR 2009). There is a central chain of active volcanoes, many undersea, that runs through the center of Vanuatu making it also more exposed than most countries to volcanic hazards. Examples of economic impacts include the 2002 Port Vila Earthquake that caused more than USD 20 million of damage to the capital city (Lindsay 2003) and the 2005 eruption at Lake Vui on Ambae Island which caused USD 427,000 worth of damage (UNISDR 2009).

Tsunamis in Vanuatu have occurred throughout the time the islands have been occupied, commonly as a result of abrupt land movements instigated by volcanic eruption, earthquake, or gravity. A widespread tsunami reported in oral traditions (Clark 1996) was associated with the massive AD 1453 eruption of Kuwae Volcano that reconfigured the geography of part of central Vanuatu (Robin, Monzier, and Eissen 1994). In March 1875, a missionary on the island of Aneityum in southern Vanuatu reported an earthquake and tsunami "ten or eleven feet [3.1-3.4 m] above its ordinary level at springtides" that was unparalleled in living memory although local people recalled that their fathers had told them of a comparable event (Inglis 1887, 183).

Records held by the National Oceanic and Atmospheric Administration's (NOAA's) National Geophysical Center show 31 tsunamis occurred in Vanuatu between 1863 and 2011, almost certainly an underestimate from incomplete reporting (NOAA 2012). Of these tsunamis, the most recent to have had a maximum water height above $6 \mathrm{~m}$ occurred at 13.21 UTC (or 00.21 local time) on 26 November 1999 as a result of a Mw7.5 earthquake near the northern tip of Ambrym Island (Regnier et al. 2003). The effects of this on the southern part of the nearby island of Pentecost are the subject of this study.

\section{The November 1999 Tsunami in Baie Martelli, Pentecost Island}

The November 1999 tsunami in north-central Vanuatu (Figure 1) affected most coasts in the area (Ioualalen et al. 2006). One of those affected most, owing to its geometry, was Baie Martelli in southern Pentecost Island which was selected as the study area for this research. Tsunami wave height reached 5.2-5.4 $\mathrm{m}$ in the western part of the bay and 6.0$6.6 \mathrm{~m}$ in the north-eastern part at the now-abandoned village named Baie Martelli (Caminade et al. 2000) although a popular account put this figure at $10 \mathrm{~m}$ (Neil-Jones 1999). Despite this, the tsunami claimed only five lives in the area out of a threatened population of about 300 , something attributed by several authors (Caminade et al. 2000; Pelletier et al. 2000; Synolakis and Okal 2005) to

- the alertness of many people, given that there had been a wedding earlier in the day and a continuing party that evening, and that the night was well moonlit;

- the ability of key people to recognize the precursors of the tsunami and use this understanding to get people to move out of harm's way. This ability came mainly from (1) indigenous knowledge, handed down through oral traditions (including myths), and (2) the memory of a video about the 1998 Aitape Tsunami (in Papua New Guinea) shown to the villagers just three weeks earlier by the National Disaster Management Office (NDMO).

Two weeks of fieldwork were carried out in southern Pentecost Island in March 2011 in order to gather specific information about the 1999 tsunami. Figure 2 shows a map of the Baie Martelli area, including all villages visited. Baie Martelli Village was the largest in the area before the 1999 tsunami but, following its destruction, survivors established two new villages (Londar and Rahnahgahgal) as well as extending most of the rest.

On the night of the tsunami, almost half an hour past midnight, the entire southern part of Pentecost Island experienced 




Figure 1. The islands of north-central Vanuatu showing the location of Baie Martelli

strong shaking, measuring 8 on the Mercalli Scale (Pelletier et al. 2000), that is reported to have lasted 10-15 minutes in Baie Martelli. Once the shaking ceased, a group of men (including three interviewed for this study) ran to the shoreline to see whether the water would recede knowing that, were this to happen, a tsunami was likely to follow. It did eventually recede almost $200 \mathrm{~m}$ out into the bay but, once this began to be noticed, the men ran back into the village shouting to the people to run into the bushland and up into the hills behind the village. Understanding a tsunami to be imminent, most people obeyed and knew not to pause unduly for any reason. Of the five people killed, one was too old to move quickly, one tried to gather his belongings before leaving, and three were reported to be intoxicated with kava. ${ }^{\text {i }}$

Following the recession of the sea, there were two tsunami waves, arriving 15 minutes apart, both reported by interviewees to have attained heights of more than $5 \mathrm{~m}$. Observers above Poinkros Village considered that the waves came from a southeast direction, first hitting the point on the western side of the bay, and then coming back to run across Baie Martelli Village and hitting the shoreline below Poinkros. These observers claim to have seen the waves increase in height as this happened, something to be expected as the sea floor shallowed and the waves were funnelled into the bay; it has been suggested that these tsunami waves had been amplified by local submarine landsliding (Caminade et al. 2000).

In Baie Martelli Village, except for the concrete church, all other buildings, typically constructed from wood with woven-grass walls and corrugated-iron roofs, were destroyed by the tsunami waves. Reports that one tsunami wave penetrated $500 \mathrm{~m}$ into the coastal plain behind Baie Martelli 


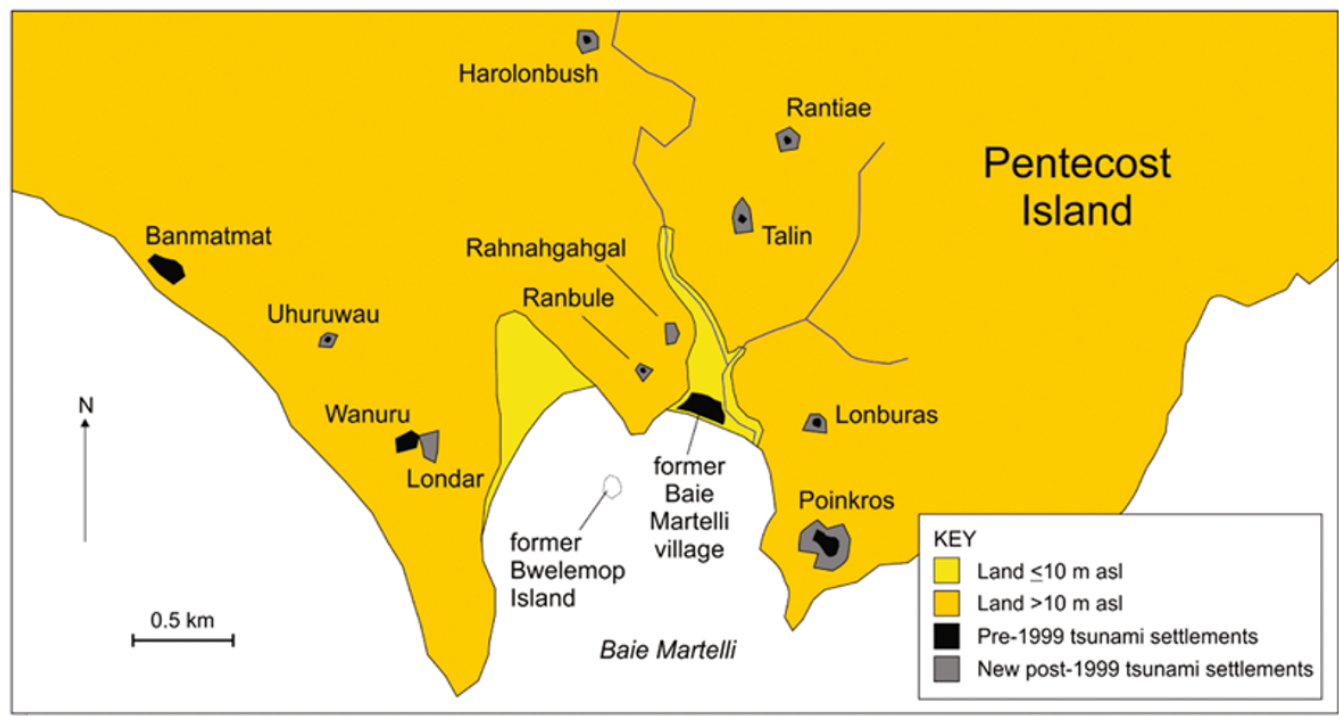

Figure 2. The study area in southern Pentecost Island, Vanuatu

Village and reached at least $1 \mathrm{~km}$ up the channel of the adjacent river (Neil-Jones 1999) were confirmed in interviews for this study. The remarkably effective response of the people of Baie Martelli has been widely commented on and, although the church in the old village is still used, no-one now lives on this site.

It is clear that the survival of so many people in Baie Martelli during the 1999 tsunami was due to a combination of fortuitous and unusual alertness, recent awareness raising, and indigenous knowledge. Most commentators on this event suggest that the latter was the least important (Caminade et al. 2000; Synolakis and Okal 2005).

\section{Kastom and Oral Traditions in Southern Pentecost Island}

The key to national identity in Vanuatu is kastom, defined as cultural products derived from precolonial knowledge and practice. More than this, kastom comprises ideologies and activities formulated in terms of empowering indigenous traditions and practices (Akin 2004). The word is a Bislama adaptation of the English word "custom" but the concept of kastom is highly emotive to most Ni-Vanuatu and its interpretation is ambiguous and varied. Use of the word kastom early in the postcontact era was laden with negative connotations as a result of colonists and missionaries using the word to signify noncompliance with their religious and economic systems. During the 1960s, largely as a result of radio broadcasts of kastom stories and songs, kastom became valued once again as a measure of cultural worth (Bolton 1999).

An important aspect of kastom is storytelling, which is used as a medium to communicate histories and cultural information across generations. Stories may be built over long periods of time as a result of continuous interaction between the story-makers and their environment. Disasters often initiate stories in their own right, which are encoded within the traditional beliefs and worldview of the people. For example, a volcanic eruption may be passed down through kastom stories as a sorcerer igniting a volcano by magic, the loss of its contents explained as theft or the stone-throwing by supernatural beings, the dropping of this material far away as creating new islands (Vitaliano 1973; Taylor 1995). These stories then form the basis of local people's understanding of such hazards and how best to respond to them should they recur.

The reliability of kastom stories (and comparable traditions) linked to volcanism and earthquakes is debated, particularly in respect to the effects of intergenerational retelling that include event amalgamation, embellishment for entertainment, and the impacts of changing belief systems (Cronin and Cashman 2008; Nunn 2009b). Yet there are innumerable examples of the utility of such stories in enabling local people to apprehend, avoid, or escape recurrent hazard, ranging from the about 7000-year old Klamath tradition about the danger of Mt. Mazama in the western USA (Barber and Barber 2004) to the smong tradition of people on Simeulue Island in Indonesia that enabled them to escape the impact of the 2004 Indian Ocean Tsunami (McAdoo et al. 2006).

\section{Methods}

This study had two goals: first, to understand what had informed the responses of the people of Baie Martelli to the 1999 tsunami that led them to escape with their lives and second, to understand their preparedness for a similar event in the future. 
In March 2011, 55 interviews were conducted in the villages of southern Pentecost, 18 with adult females, 37 with adult males (Figure 3). Local populations in each village were sampled using the snowball method, whereby a local gatekeeper identified interviewees based on interviewer guidance; the number interviewed in each village was roughly proportional to its population. Some gender bias was expected, given that in Ni-Vanuatu society many traditional practices establish the position of women as socially indebted to men and not therefore privileged to be given the full complement of traditional knowledge that is available to them. Also interviewer gender (male) sometimes made it awkward for women to be interviewed in situations where they might speak freely, so these were avoided by potential interviewees. Finally, because women in the area generally move to their husband's village after marriage, many women encountered did not meet the 15 years residence time in the area that was felt to be the minimum needed for a person to have acquired sufficient familiarity with it—and to have experienced the 1999 tsunami.

There were also biases of age and status among the 55 persons interviewed. Given that many younger people in southern Pentecost, often more aware than their elders of the nature and possibilities of the world beyond, are ignorant, even scornful, of particular aspects of kastom, older interviewees were sought within particular households wherever possible. In terms of status, the hierarchical nature of decision-making that is common in Ni-Vanuatu society, particularly in times of exigency, generally means that higherstatus people (usually older males) have greater knowledge of traditions as well as greater influence over how and to whom these are expressed.
Interviews were semi-structured, direct questions being avoided wherever possible in favor of discussion stimuli. With the consent of the interviewees, all interviews were recorded for subsequent transcription. Wherever possible, interviews were carried out without an audience to prevent possible bias in an interviewee's answers. While most persons interviewed seemed comfortable being asked to recount particular oral traditions and answering questions about them, it is accepted that certain information might have been withheld.

\section{Results and Discussion}

Much of the information gathered came from kastom knowledge, which was articulated by only some interviewees. 12 interviewees ( $22 \%$ of sample) with an average age of 62 had detailed kastom knowledge; nine were male elders or chiefs, two were sons of chiefs; the sole woman was more than 90 years old. 30 interviewees (55\%) with an average age of 39 expressed little kastom knowledge but supplied basic information about past tsunamis; of these, 22 were male and eight female. The remaining 13 interviewees (24\%) with an average age of 35 had little information other than that there had been tsunamis in the past; nine were female and four male. It is considered that the interviewees responded honestly and that their answers were not significantly biased by new understanding postdating the 1999 tsunami, not least because there have not been any subsequent tsunamis in Baie Martelli.

While considerable ancillary information was gathered through interview discussions, the remainder of this article looks solely at the two issues that are key to the study.

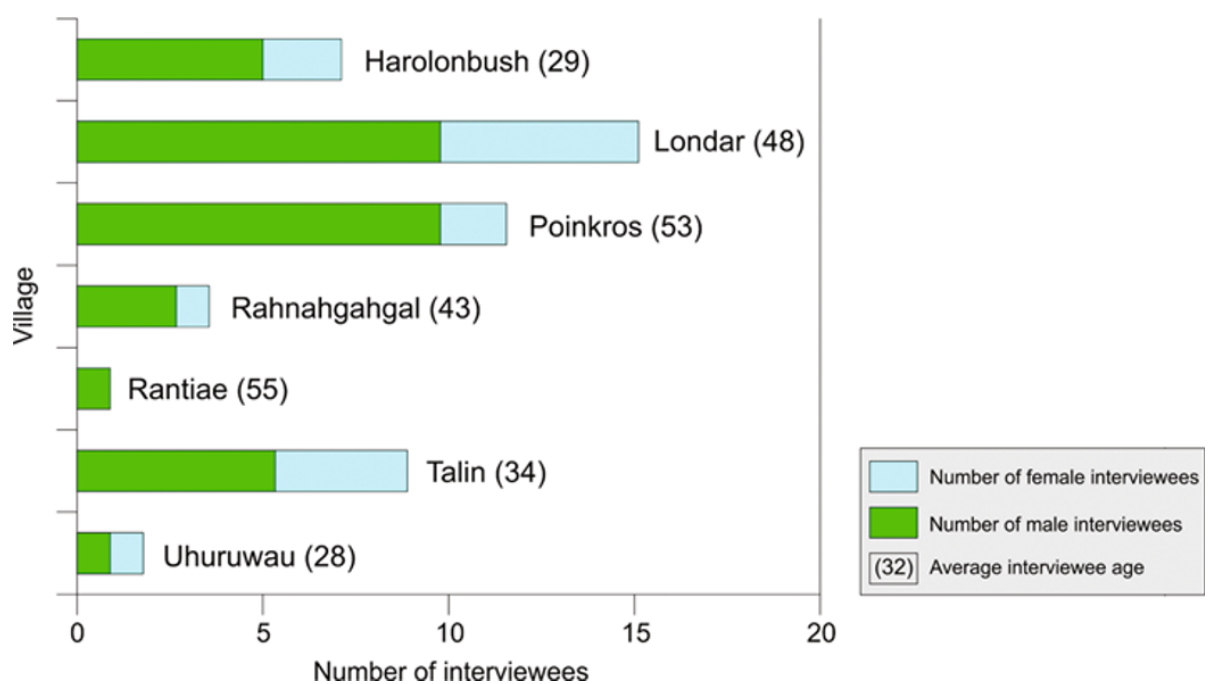

Figure 3. Gender and age of persons interviewed in Southern Pentecost Island, Vanuatu, March 2011 


\subsection{Pre-1999 Tsunami Response Awareness}

There were found to be two principal sources of information about tsunamis in Baie Martelli: indigenous knowledge, typically passed intergenerationally through oral traditions and including myths (legends), and the NDMO video about the 1998 Aitape Tsunami shown to the people of southern Pentecost three weeks before the 1999 tsunami. Of the two sources, the efficacy of the latter is easier to isolate.

25 of the 55 interviewees $(45 \%)$ had either viewed the NDMO video or had heard about it before the 1999 tsunami; the remaining 55\% had not. Of the main messages from the video, that associating the unusual and rapid recession of the water away from the shoreline with a series of large and destructive waves was that which $10(40 \%)$ of these 25 interviewees remembered most clearly, although it is possible that this memory became more prominent subsequently precisely because of the 1999 tsunami. The three interviewees who had run to the shoreline of Baie Martelli when the ground tremors ceased were among these 10 and claim their action was to look for signs of the ocean starting to recede. Once they saw this, they were able to alert the rest of the village.

The imperative of escaping the imminent tsunami waves by running into the bush behind the village and up into the hills was less clearly remembered as a result of the NDMO video, perhaps because no such refuges were available to many inhabitants of Aitape on whose experiences the video was based. ${ }^{\text {ii }}$ Rather it was explained that sufficient people in Baie Martelli Village knew that they had to escape quickly in a direction away from the sea, so they ran landwards and called upon others in the community to do the same. Many interviewees were not in a position to evaluate their motivation in running landwards, being accustomed to following instructions and the example of others, trusting them to be appropriately informed.

The final point about the video that was expressed by several interviewees was that, had a tsunami not occurred in Baie Martelli three weeks after the video was shown, its messages would have been considered as lacking context and would likely have been quickly forgotten. Yet the fact that the video and the tsunami occurred so close together means that the message of the first became fused with the experience of the second (and revived memories of earlier tsunamis); 43 interviewees ( $79 \%$ of the sample) said that they tell stories about tsunamis to young people and other villagers.

In order to understand indigenous knowledge concerning tsunamis that occurred prior to the 1999 tsunami, interviewees were first asked whether they knew of any tsunamis that had occurred prior to this event and, if yes, how many. Somewhat surprisingly, given the official records of past tsunamis in Vanuatu (31 tsunamis in all Vanuatu since 1863) (NOAA 2012), most interviewees (52 or 94\%) knew of at least one tsunami to have entered Baie Martelli before the 1999 event; $29(53 \%)$ knew of one tsunami, $15(27 \%)$ of two tsunamis, and eight (14\%) with an average age of $50 \mathrm{knew}$ of three tsunamis. Note that these are not necessarily tsunamis that occurred during the lifetime of the interviewee but may be those experienced by ancestors; it was sought to exclude legendary accounts (by explicit request to each interviewee) from these data.

As noted above, just 12 interviewees (22\%) had detailed kastom knowledge about natural hazards; other interviewees may have known kastom stories but were not at liberty to tell them. Even among the 12 interviewed, it was clear that some owned particular stories and were therefore at liberty to repeat them if they chose while others were not. From the considerable mass of material gathered from kastom sources, two myths obtained from multiple sources are considered likely to recall former tsunami events in Baie Martelli. These are the Devil at Lonburas (Dun Neias) story from the east of the bay, and the Wild Fowl story from the west. These two are summarized and interpreted separately below.

\section{The Devil at Lonburas \\ There was once a devil (named Ias) who lived in a cave out- side Lonburas Village. Every day he came to the village when food (lap-lap) was being prepared and consumed huge amounts including the tables on which it was served. The vil- lagers decided to rid themselves of the devil so questioned him to try to discover what scared him. Ias revealed this to be saltwater, so the villagers went down to the bay and collected saltwater in a special kastom leaf, brought it back to the Kastom Man in Lonburas who poured it into a hole in a black palm tree. The Kastom Man sang a song that made the salt- water rise up inside the tree, urging the ocean to come and join it. When the song ended the villagers heard the sound of a wave rushing towards them and felt a strong wind. The devil awoke alarmed and asked the villagers what the noise was. The villagers joined their Kastom Man singing the song again and again until the saltwater reached Lonburas. The devil climbed a banyan tree in fear but the Kastom Man sang the song for the last time and it was immersed, swallowing the devil. The villagers cut open the devil and retrieved all the tables he had swallowed.}

This story demonstrates the common belief in many oral traditions that human magic has control over the elements and that natural hazards like tsunamis can be used to punish evil. The details of the tsunami, reaching perhaps $30 \mathrm{~m}$ above sea level at Lonburas, and drowning even those who took refuge in high trees, are likely to serve as practical information for future generations of listeners. The detail that the tables were retrieved informs the listeners that such testing situations can have positive outcomes.

The Wild Fowl Story

There were once two fowl living separately at peace with each other in Baie Martelli. One (named Sutengal) lived on low Bwelemop Island in the middle of the bay, the other (named Sutemburi) lived on a hill at Ranbule overlooking the bay. One day the fowls began shouting at each other. Sutemburi shouted from his great height that one day the saltwater would 
come and wash Sutengal from his island home. Sutengal retorted that one day the hills would no longer feed Sutemburi and he would be crying with hunger in the bush. After a while, an old man at Ranbule became so exasperated at the noise from the two fowls that he performed a powerful kastom rite that pulled saltwater over Bwelemop, killing Sutengal and drowning the island. The wave also reached Ranbule but the people (with Sutemburi) fled up the hill to safety. After the wave, there was peace in Baie Martelli but the people forgot the ancient kastom rite and could not undo it. So giant waves return to the bay again and again.

This story also demonstrates the potency of human magic but also how this can be used irresponsibly, for even the most trivial issues. The details of this tsunami, how it swamped Bwelemop Island and reached 20-25 m above sea level at Ranbule, represent important information. The story states clearly how it is possible to survive such waves by running uphill but also cautions that such waves will return again in the future.

Both these stories are comparatively well known among particular groups in southern Pentecost and, as with some others from the area (Jolly 1999), are likely to have contributed to effective responses to tsunamis in the past. It could be argued that the sole purpose for which these stories were created was to inform future generations, through the medium of oral traditions, that tsunamis do routinely affect Baie Martelli and that it is safer not to live in the low-lying areas and to run uphill when tsunamis appear imminent. Comparable stories are found among other indigenous groups in tsunami-prone places (McMillan and Hutchinson 2002; King, Goff, and Skipper 2007).

There is another level of folk knowledge about tsunamis prevalent among people in southern Pentecost, which was recorded from some of the 30 interviewees who, while not able to repeat kastom stories, did have anecdotes that serve to remind the people of the area about the vulnerability of Baie Martelli to tsunamis. Four of these are summarized below.

- An old woman drowned in a pre-1999 tsunami in Baie Martelli was buried in a prominent place and a namele (Cycas seemannii) tree planted nearby to mark the spot. Although the tree is long gone, the place and its associations are well known among people in the villages of southern Pentecost.

- At a point 30 minutes walk upriver from the site of former Baie Martelli Village (about $1.3 \mathrm{~km}$ from the coast) there is a pool in which saltwater fish including a wrasse (probably Cheilinus undulatus) were allegedly found alive following an earlier (pre-1999) tsunami.

- The location of Bwelemop Island in Baie Martelli is readily visible at low tide today and well-known to local people as an island that was destroyed by a giant wave. This was reported by seven (23\%) of this group of informants as factual information, not linked to the kastom story of the wild fowl (above).

- Nine interviewees (30\%) told the story of how once a giant wave had washed from west to east over the headland in north-central Baie Martelli at a height of well over $50 \mathrm{~m}$. The route the wave took was known to a few.

All these anecdotes, more factual and therefore perhaps less memorable (and hence less suited to oral tradition), recall the effects of tsunamis in Baie Martelli and are likely to have contributed to the awareness of the people living there in 1999 about how to respond to tsunami precursors.

\subsection{Preparedness for Future Tsunamis}

On the face of it, it might seem that the people of southern Pentecost are already well-informed about tsunami hazards.

- They have a memory of a recent (1999) tsunami that is ingrained in social structures through the dispersal of people from the former Baie Martelli Village throughout the area.

- They have had official communication from the Vanuatu Government through the NDMO video about the threat of tsunamis and how to respond appropriately to them.

- And they have a number of folk memories, both within and outside the kastom context, that are probably known to at least half the adult population within the area.

Yet, as more than one elderly interviewee reflected, such knowledge tends to be lost quite readily. He explained that when people of southern Pentecost have a high awareness of tsunami risk, they have lived away from the coasts (as they do now) but, as this knowledge fades (as might be expected after long periods without tsunamis), they slowly move back to the coasts where life is generally easier. A similar phenomenon was reported at Aitape in Papua New Guinea where there is also a long history of tsunami incidence (Davies 2002).

There is no scientific information on the recurrence interval of tsunamis affecting Baie Martelli, but a figure of 50-120 years appears reasonable given the (incomplete) scientific record and the oral traditions about the numbers of recalled pre-1999 tsunamis (see above). During the field survey for this study, it was clear that not every interviewee felt the threat of future tsunamis in Baie Martelli equally. For while most participants felt that another tsunami was likely within the next 100-200 years, these were mostly male and included all persons over 54 years old; most females said they were not sure (Table 1). Younger people were less convinced of tsunami risk than older people, which signals a danger that, in the absence of a tsunami event in the area, they or their 
Table 1. Perceived likelihood of a future tsunami in Baie Martelli, Pentecost Island, Vanuatu

\begin{tabular}{|c|c|c|c|c|c|c|}
\hline & $\begin{array}{c}\text { Extremely Likely } \\
\text { within } 100 \text { Years }\end{array}$ & $\begin{array}{l}\text { Likely within } \\
\text { 100-200 Years }\end{array}$ & $\begin{array}{l}\text { Unlikely within } \\
\text { 200-300 Years }\end{array}$ & $\begin{array}{c}\text { Extremely Unlikely } \\
\text { within } 300 \text { Years }\end{array}$ & Not Sure & Total \\
\hline Number of participants & 13 & 17 & 6 & 3 & 16 & 55 \\
\hline Average age & 49 & 51 & 35 & 31 & 35 & \\
\hline Number $(\%)$ of males & $10(26 \%)$ & $15(40 \%)$ & $4(11 \%)$ & $3(8 \%)$ & $6(16 \%)$ & 38 \\
\hline Number $(\%)$ of females & $2(12 \%)$ & $3(18 \%)$ & $2(12 \%)$ & 0 & $10(59 \%)$ & 17 \\
\hline Number $(\%)$ of persons $>54$ years old & $6(46 \%)$ & $7(54 \%)$ & 0 & 0 & 0 & 13 \\
\hline
\end{tabular}

descendants may indeed move back to tsunami-prone locations.

Given the importance of indigenous knowledge in informing responses to the 1999 tsunami, future behavior and exposure to tsunami hazards is likely to depend to a large extent on the continued preservation and oral transmission of kastom stories (and other traditions) concerning past tsunami impacts. Other sources of information, such as the NDMO video, are of dubious relevance to the situation in Vanuatu and are experienced by people in places like southern Pentecost Island so infrequently that they are likely to be of low importance in informing future responses. There is therefore a pragmatic imperative for ensuring that indigenous knowledge is preserved in such situations and that its dissemination is not unduly hindered by social status or gender.

\section{Conclusions}

Indigenous knowledge, largely through kastom, appears to have played a more significant role in the successful response by the people of Baie Martelli Village to the 1999 tsunami than previously acknowledged. The NDMO video, which earlier commentators regarded as the prime motivator (Caminade et al. 2000; Synolakis and Okal 2005) clearly played a role but its messages were not as widely known or appreciated at the time of the 1999 tsunami. This underlines the value given to traditional knowledge by indigenous people in Vanuatu and elsewhere, knowledge that they feel they own and which is relevant to their particular situation. In contrast, nonindigenous knowledge may be perceived as alien, particularly when it is communicated in an unfamiliar language and/or uses unfamiliar concepts, and is consequently undervalued (Mortreux and Barnett 2009; Nunn 2009a; Lata and Nunn 2011).

In terms of articulating effective responses to disasters like tsunamis, these conclusions emphasize the importance of maintaining and sustaining sources of indigenous knowledge in such communities but also, given its limitations, blending it with nonindigenous (scientific) knowledge in ways that make it palatable to these communities; a similar conclusion was reached from a study of volcanic hazard awareness on
Ambae Island in Vanuatu (Cronin et al. 2004). As with any messages about disaster risk or, more broadly, environmental management, the goal is to achieve whole-community buy-in, so that the greatest possible number of people can take appropriate action when necessary. In the Pentecost context, in practical terms, this means that

- steps should be taken to ensure the survival of relevant kastom knowledge in such communities, including trying (1) to remove its essence from elite ownership, given the threat this poses to the sustainability of this aspect of indigenous knowledge, and (2) to rectify the gender imbalance around this knowledge, on the grounds that it is equally a threat to its sustainable long-term utility;

- government should continue to disseminate messages using appropriate media about disaster risk and response to communities throughout Vanuatu that acknowledge indigenous language and culture.

This study has highlighted the importance of indigenous knowledge and its value in engaging peripheral communities in developing countries in disaster risk management, which is being increasingly acknowledged as central to development agendas (Mercer et al. 2007; Mercer et al. 2010).

\section{Acknowledgments}

The researchers wish to acknowledge the assistance of the Vanuatu Cultural Center which approved the project and gave assistance and logistical support, as well as the Geo-Hazards Unit within the Department of Meteorology, Geology, Mines and Water Resources of the Government of Vanuatu. Augustine Tabac from Poinkros Village in Baie Martelli on Pentecost Island acted as guide, translator, and gatekeeper. We acknowledge the kastom owners of the myths who gave their permission for them to be published in this study; for the Devil at Lonburas, we recognize Noel Bule, Wilson Bule, Mable Chiren, and Joel Tamtam of Poinkros Village; for the Wild Fowl, we recognize Celester Magi of Rahnahgahgal Village, Cyriaque Olul and Marcel Sali of Londar Village, and Peter Tatu of Rantiae Village. 


\section{Notes}

i Kava is a soporific drink, traditionally consumed both socially and during ceremonies in Vanuatu (and other western Pacific Island groups), made from the roots of native pepper plants (most commonly, Piper methysticum).

ii More than 1600 people were killed by the Aitape Tsunami on 17 July 1998 and 10,000 forced to relocate inland. Many villages affected were located on low narrow sand spits between the ocean and an inland (coastal) lagoon, which made it impossible for most of their inhabitants to get out of the path of the tsunami.

\section{References}

Agrawal, A. 1995. Dismantling the Divide Between Indigenous and Scientific Knowledge. Development and Change 26 (3): 413-39.

Akin, D. 2004. Ancestral Vigilance and the Corrective Conscience. Anthropological Theory 4 (3): 299-324.

Barber, E. W., and P. T. Barber. 2004. When They Severed Earth from Sky: How the Human Mind Shapes Myth. Princeton: Princeton University Press.

Bolton, L. 1999. Radio and the Redefinition of Kastom in Vanuatu. Contemporary Pacific 11 (2): 335-60.

Caminade, P., D. Charlie, U. Kanoglu, S.-I. Koshimura, H. Matsutomi, A. Moore, C. Ruscher, C. Synolakis, and T. Takahashi. 2000. Vanuatu Earthquake and Tsunami Cause Much Damage, Few Casualties. EOS, Transactions American Geophysical Union 81 (52): 641-47.

Clark, R. 1996. Linguistic Consequences of the Kuwae Eruption. In Oceanic Culture History: Essays in Honour of Roger Green, edited by J. M. Davidson, G. Irwin, B. F. Leach, A. Pawley, and D. Brown, 275-85. Wellington, New Zealand: New Zealand Journal of Archaeology.

Cronin, S. J., and K. V. Cashman. 2008. Volcanic Oral Traditions in Hazard Assessment and Mitigation. In Living under the Shadow: Cultural Impacts of Volcanic Eruption, edited by J. Gratton and R. Torrence, 175-202. Oakland, California: Left Coast Press.

Cronin, S. J., D. R. Gaylord, D. Charley, B. V. Alloway, S. Wallez, and J. W. Esau. 2004. Participatory Methods of Incorporating Scientific with Traditional Knowledge for Volcanic Hazard Management on Ambae Island, Vanuatu. Bulletin of Volcanology 66 (7): 652-68.

Davies, H. 2002. Tsunamis and the Coastal Communities of Papua New Guinea. In Natural Disasters and Cultural Change, edited by R. Torrence and J. Grattan, 28-42. London: Routledge.

Gaillard, J.-C., E. Clavé, O. Vibert, A. Azhari, D. Dedi, J.-C. Denain, Y. Efendi, D. Grancher, C. Liamzon, D. Sari, and R. Setiawan. 2008. Ethnic Groups' Response to the 26 December 2004 Earthquake and Tsunami in Aceh, Indonesia. Natural Hazards 47 (1): 17-38.

Galipaud, J.-C. 2002. Under the Volcano: Ni-Vanuatu and Their Environment. In Natural Disasters and Cultural Change, edited by R. Torrence and J. Grattan, 162-71. London: Routledge.

Gregg, C. E., B. F. Houghton, D. Paton, R. Lachman, J. Lachman, D. M. Johnston, and S. Wongbusarakum. 2006. Natural Warning Signs of Tsunamis: Human Sensory Experience and Response to the 2004 Great Sumatra Earthquake and Tsunami in Thailand. Earthquake Spectra 22 (S3): S671-91.

Inglis, J. 1887. In the New Hebrides: Reminiscences of Missionary Life and Work, Especially on the Island of Aneityum, from 1850 till 1877. London: Nelson.

Ioualalen, M., B. Pelletier, P. Watts, and M. Regnier. 2006. Numerical Modeling of the 26 November 1999 Vanuatu Tsunami. Journal of Geophysical Research 111 (C6): C06030-42.

Jolly, M. 1999. Another Time, Another Place. Oceania 69 (4): 282-99.
Kelman, I., and J. C. Gaillard. 2010. Embedding Climate Change Adaptation within Disaster Risk Reduction. In Climate Change Adaptation and Disaster Risk Reduction: Issues and Challenges, edited by R. Shaw, J. M. Pulhin, and J. J. Pereira, 23-46. Bradford, UK: Emerald.

King, D. N. T., J. Goff, and A. Skipper. 2007. Māori Environmental Knowledge and Natural Hazards in Aotearoa-New Zealand. Journal of the Royal Society of New Zealand 37 (2): 59-73.

Lata, S., and P. Nunn. 2011. Misperceptions of Climate-Change Risk as Barriers to Climate-Change Adaptation: A Case Study from the Rewa Delta, Fiji. Climatic Change 110 (1-2): 1-18.

Lindsay, K. 2003. Preliminary Report on Vanuatu Government Risk Management System. Port Vila, Vanuatu: Riskman International.

McAdoo, B. G., L. Dengler, G. Prasetya, and V. Titov. 2006. Smong: How an Oral History Saved Thousands on Indonesia's Simeulue Island during the December 2004 and March 2005 Tsunamis. Earthquake Spectra 22 (S3): S661-69.

McAdoo, B. G., A. Moore, and J. Baumwoll. 2009. Indigenous Knowledge and the Near Field Population Response during the 2007 Solomon Islands Tsunami. Natural Hazards 48 (1): 73-82.

McKenzie, E., B. C. Prasad, and A. Kaloumaira. 2005. Economic Impact of Natural Disasters on Development in the Pacific. Suva, Fiji: SOPAC (South Pacific Applied Geoscience Commission).

McMillan, A. D., and I. Hutchinson. 2002. When the Mountain Dwarfs Danced: Aboriginal Traditions of Paleoseismic Events along the Cascadia Subduction Zone of Western North America. Ethnohistory 49 (1): 41-68.

Mercer, J. 2010. Disaster Risk Reduction or Climate Change Adaptation: Are We Reinventing the Wheel? Journal of International Development 22 (2): 247-64.

Mercer, J., D. Dominey-Howes, I. Kelman, and K. Lloyd. 2007. The Potential for Combining Indigenous and Western Knowledge in Reducing Vulnerability to Environmental Hazards in Small Island Developing States. Environmental Hazards 7 (4): 245-56.

Mercer, J., I. Kelman, L. Taranis, and S. Suchet-Pearson. 2010. Framework for Integrating Indigenous and Scientific Knowledge for Disaster Risk Reduction. Disasters 34 (1): 214-39.

Mortreux, C., and J. Barnett. 2009. Climate Change, Migration and Adaptation in Funafuti, Tuvalu. Global Environmental Change 19 (1): 105-12.

Neil-Jones, M. 1999. Very Lucky to Be Alive. Trading Post Vanuatu, 1 December 1999, 1, 4.

NOAA (National Oceanic and Atmospheric Administration). 2012. NOAA National Geophysical Data Center, Natural Hazards, Tsunami Events. National Oceanic and Atmospheric Administration, US Department of Commerce. http://www.ngdc.noaa.gov/hazard/hazards. shtml.

Nunn, P. D. 2009a. Responding to the Challenges of Climate Change in the Pacific Islands: Management and Technological Imperatives. Climate Research 40 (2-3): 211-31.

Nunn, P. D. 2009b. Vanished Islands and Hidden Continents of the Pacific. Honolulu: University of Hawai'i Press.

Olorunfemi, F. B., and R. U. Adebimpe. 2008. Sustainable Disaster Risk Reduction in Nigeria: Lessons for Developing Countries. African Research Review 2 (2): 187-217.

Pelletier, B., M. Régnier, S. Calmant, R. Pillet, G. Cabioch, Y. Lagabrielle, J.-M. Bore, J.-P. Caminade, P. Lebellegard, I. Cristopher, and S. Temakon. 2000. Le séisme d'Ambrym-Pentecôte (Vanuatu) du 26 novembre 1999 (Mw 7.5): données préliminaires sur la séismicité, le tsunami et les déplacements associés. Comptes Rendus de l'Académie des Sciences - Series IIA - Earth and Planetary Science 331 (1): 21-28.

Pelling, M., and J. I. Uitto. 2001. Small Island Developing States: Natural Disaster Vulnerability and Global Change. Global Environmental Change Part B: Environmental Hazards 3 (2): 49-62. 
Regnier, M., S. Calmant, B. Pelletier, Y. Lagabrielle, and G. Cabioch. 2003. The Mw 7.5 1999 Ambrym Earthquake, Vanuatu: A Back Arc Intraplate Thrust Event. Tectonics 22 (4): 1034-47.

Robin, C., M. Monzier, and J.-P. Eissen. 1994. Formation of the MidFifteenth Century Kuwae Caldera (Vanuatu) by An Initial Hydroclastic and Subsequent Ignimbritic Eruption. Bulletin of Volcanology 56 (3): $170-83$.

Schipper, L., and M. Pelling. 2006. Disaster Risk, Climate Change and International Development: Scope for, and Challenges to, Integration. Disasters 30 (1): 19-38.

Shaw, R., A. Sharma, and Y. Takeuchi. 2009. Indigenous Knowledge and Disaster Risk Reduction: From Practice to Policy. New York: Nova Science Publishers.

Synolakis, C. E., and E. A. Okal. 2005. 1992-2002: Perspective on a Decade of Post-Tsunami Surveys. In Tsunamis: Case Studies and
Recent Developments, edited by K. Satake, 1-29. Dordrecht: Springer.

Takeuchi, Y., F. Mulyasari, and R. Shaw. 2011. Roles of Family and Community in Disaster Education. Community, Environment and Disaster Risk Management 7: 77-94.

Taylor, P. W. 1995. Myths, Legends and Volcanic Activity-An Example from Northern Tonga. Journal of the Polynesian Society 104 (3): 323-46.

UNISDR (United Nations International Strategy for Disaster Reduction). 2009. Risk and Poverty in a Changing Climate: UNISDR Global Assessment on Disaster Risk Reduction. Geneva: United Nations International Strategy for Disaster Reduction Secretariat.

Vitaliano, D. 1973. Legends of the Earth: Their Geologic Origins. Bloomington: Indiana University Press.

Open Access This article is distributed under the terms of the Creative Commons Attribution License which permits any use, distribution, and reproduction in any medium, provided the original author(s) and source are credited. 